\title{
Personality and field of study choice
}

Citation for published version (APA):

Humburg, M. (2014). Personality and field of study choice. ROA. ROA Research Memoranda No. 001 https://doi.org/10.26481/umaror.2014001

Document status and date:

Published: 01/01/2014

DOI:

10.26481/umaror.2014001

Document Version:

Publisher's PDF, also known as Version of record

\section{Please check the document version of this publication:}

- A submitted manuscript is the version of the article upon submission and before peer-review. There can be important differences between the submitted version and the official published version of record.

People interested in the research are advised to contact the author for the final version of the publication, or visit the DOI to the publisher's website.

- The final author version and the galley proof are versions of the publication after peer review.

- The final published version features the final layout of the paper including the volume, issue and page numbers.

Link to publication

\footnotetext{
General rights rights.

- You may freely distribute the URL identifying the publication in the public portal. please follow below link for the End User Agreement:

www.umlib.nl/taverne-license

Take down policy

If you believe that this document breaches copyright please contact us at:

repository@maastrichtuniversity.nl

providing details and we will investigate your claim.
}

Copyright and moral rights for the publications made accessible in the public portal are retained by the authors and/or other copyright owners and it is a condition of accessing publications that users recognise and abide by the legal requirements associated with these

- Users may download and print one copy of any publication from the public portal for the purpose of private study or research.

- You may not further distribute the material or use it for any profit-making activity or commercial gain

If the publication is distributed under the terms of Article $25 \mathrm{fa}$ of the Dutch Copyright Act, indicated by the "Taverne" license above, 
Maastricht University

Research Centre for Education and the Labour Market | ROA

\section{Personality and field of study choice}

Martin Humburg

\section{ROA Research Memorandum}

ROA-RM-2014/1

Research Centre for Education and the Labour Market Maastricht University

P.O. Box 616, 6200 MD Maastricht, The Netherlands

$\mathrm{T}+31433883647 \mathrm{~F}+31433884914$

secretary-roa-sbe@maastrichtuniversity.nl www.roa.nl 


\title{
Personality and field of study choice
}

\author{
Martin Humburg
}

ROA-RM-2014/1*

January 2014

Research Centre for Education and the Labour Market

Maastricht University

P.O. Box 616, 6200 MD Maastricht, The Netherlands

$\mathrm{T}+31433883647 \mathrm{~F}+31433884914$

secretary-roa-sbe@maastrichtuniversity.nl

www.roa.nl

\footnotetext{
* The ROA Research Memorandum Series was created in order to make research results available for discussion, before those results are submitted for publication in journals.
} 


\section{Abstract}

\section{Personality and field of study choice**}

Field of study choice has far-reaching implications for individuals enrolling in university. Field of study choice is strongly linked to the subject matter graduates will specialize in, the kind of work environment they will be working in, and the returns to their skills they can expect once they enter the workforce. This paper uses unique Dutch data which demonstrates that personality measured at age 14 can be linked to field of study choice at around age 19. It can be shown that the Big Five personality traits affect field of study choice. Moreover, while personality matters less than cognitive skills, such as math ability and verbal ability, for educational attainment, the influence of personality on field of study choice is comparable to that of cognitive skills. Sorting across fields of study on the basis of personality traits is in some respects similar for women and men, although substantial differences exist.

JEL classification: I21, J24

Keywords: personality, non-cognitive skills, cognitive skills, field of study choice, Big Five, educational attainment

Martin Humburg

ROA

P.O. Box 616

NL-6200 MD Maastricht

The Netherlands

m.humburg@maastrichtuniversity.nl

** I am grateful to Eric Bonsang, Andries de Grip, Ingrid Rohde, Tom Stolp, Tanja Traag, Rolf van der Velden and conference participants at the 2nd Lisbon Research Workshop on Economics, Statistics and Econometrics of Education 2013, SOLE 2013 in Boston and EALE 2013 in Turin for their discussions and comments on earlier versions of this paper. 


\section{Introduction}

Individuals' personality traits are related to a variety of educational and labour market outcomes. For example, personality traits have been shown to affect individuals' academic performance in school, as well as their probability of finishing secondary school, attending university, and obtaining a university degree (Heckman, Stixrud and Urzua, 2006; Cunha and Heckman, 2007; O'Connor and Paunonen, 2007; Borghans, Duckworth, Heckman and ter Weel, 2008; Barón and Cobb-Clark, 2010). After leaving education, personality traits influence individuals' probability of being employed (Heckman et al. 2006) as well as their earnings (Nyhus and Pons, 2005; Mueller and Plug, 2006, Heineck and Anger, 2010). The present paper explores the relationship between the Big Five personality traits and another important educational outcome: field of study choice. Field of study choice has far-reaching implications for individuals enrolling in university. As fields of study are strongly linked to occupations, choosing a particular field of study narrows down the job options available to individuals after graduation. Field of study choice is therefore strongly linked to the subject matter graduates will specialize in, the kind of work environment they will be working in, and the returns to their skills they can expect once they enter the workforce.

Expected life time earnings have long been identified as one of the major determinants of field of study choice (Berger, 1988; Flyer, 1997; Arcidiacono, 2004; Arcidiacono, Hotz and Kang, 2012; Wisfall and Zafar, 2013). Individuals have been shown to be aware of careers which maximize their expected life time earnings given their abilities, and they tend to choose their field of study accordingly. However, Arcidiacono (2004) and Wiswall and Zafar (2013) have recently argued that expected life time earnings may be less important than what Arcidiacono (2004) calls preference for "subject matters" and what Wiswall and Zafar (2013) refer to as the "enjoyability of coursework". Of particular importance to my study, Arcidiacono (2004) shows that cognitive skills are related to both these determinants of field of study choice: math ability and verbal ability influence field of study choice by generating different returns in different occupational fields, and by being related to the preference and taste for doing math or tasks related to using verbal ability.

This paper presents evidence that personality traits influence field of study choice in much the same way cognitive skills do. I argue that individuals with particular personality traits a) enjoy some fields of study and related occupations more than others and b) are more productive in some fields of study and related occupations than others. The main contribution of this study is thus the inclusion of individual differences in utility functions as captured by the Big Five personality traits - extraversion, agreeableness, conscientiousness, emotional stability and openness to experience - into the prediction of individuals' field of study.

As alluded to above, previous research has shown that individuals choose subject matters and jobs which they like and which they are good at. Both enjoying tasks and being good at them is likely to increase productivity in these tasks. Evidence that this may be related to the Big Five personality traits has been found in both the economic literature and the literature on vocational psychology. Holland (1997) has documented that individuals choose their work environments on the basis of their vocational interests, and de Fruyt and Mervielde (1997) have found that vocational interests and the Big Five personality traits are related. Filer (1986) and Cobb-Clark and Tan (2011) show that the Big Five personality traits (or related measures in the case of Filer) are associated with individuals' occupational choice; Nyhus and Pons (2005), Mueller and Plug (2006) as well as Heineck and Anger (2010) find that the Big Five personality traits are factors of production which can be rewarded and sometimes penalized by employers. More specifically, emotional stability and agreeableness have been found to be particularly important in jobs involving large amounts of teamwork and dyadic customer interaction (Mount, Barrick and Steward, 1998). Judge and Cable (1997) find that more agreeable job seekers are more attracted to supportive and team-oriented organizational cultures and less attracted to aggressive, outcome-oriented, and decisive organizational cultures. Barrick and Mount (1991) show that extraversion is associated with higher job performance in management and sales occupations. Cattan $(2010)^{1}$ shows that sociability, a trait related to extraversion, is rewarded in some occupations and penalized in others. Controlling for selection, she finds that a standard deviation

1. Cattan's work is currently not publicly available but is reported in Almlund et al. (2011). 
increase in sociability leads to a $6 \%$ increase in the wages of managers, a $4 \%$ increase in the wages of sales workers, and a $2 \%$ increase in the wages of clerical workers, but leads to a $2 \%$ decrease in the wages of professionals. Krueger and Schkade (2008) show that extroverted persons sort into jobs which provide them with the opportunity for social contact. Borghans, ter Weel and Weinberg (2008) find that sociability in youth is related to interpersonal tasks in the occupation individuals are working in as adults. They also find that occupations differ with regard to the personality traits they demand, and that individuals are most productive in jobs which fit their personality.

Evidence for a relationship between personality traits and occupational sorting from previous studies is strongest for extroversion. Looking at the definition of the Big Five personality traits in Table 1 it is, however, easy to imagine how the other Big Five personality traits may be related to field of study and occupational career choice as well.

[Table 1]

For example, agreeableness - defined as the tendency to act in a cooperative, unselfish manner may be expected to be related to sorting into healthcare occupations and into fields of study concerned with the (well) functioning of society. Emotionally stable persons are more effective in dealing with stress than neurotic persons (Costa and McCrae, 1985) which may lower their disutility of choosing fields of study with higher workloads. Openness to experience and conscientiousness are important predictors of academic success (O'Connor and Paunonen, 2007) and may therefore be expected to be mainly relevant for educational achievement rather than field of study choice. However, they may increase the probability of entering those study programs for which access is granted on the basis of grades.

In this paper, I find that the Big Five personality traits indeed affect field of study choice. The results represent an important contribution to the literature as I am able to estimate the effect personality measured around the age of 14 will have on field of study choice four years later. This allows me to circumvent the reverse causality problem faced by analyses using contemporaneous personality measures (personality measured at the same time as field of study choice). By measuring personality well before field of study choice, I can exclude the possibility that individuals' personality has been influenced by enrolling in a particular field of study; for example, through individuals' adaptation to their peers or through behavioural stereotypes associated with particular fields of study and related occupations.

The remainder of this paper is structured as follows: The next section will explain the data as well as the econometric model and will describe the mean personality differences across educational levels and fields of study. In section 3 I will briefly show how personality traits affect educational attainment before presenting the main results on how personality traits are associated with field of study choice. I draw conclusions in section 4 .

\section{Data and methodology}

This paper uses data of a large longitudinal Dutch youth survey of 19,391 individuals who entered secondary education and were around the age of 13 in $1999 .^{2}$ Students were drawn from a random selection of 126 Dutch schools (van Berkel, 1999). The cohort has been shown to be a representative 10 percent sample of students in the first grade of secondary education in the Netherlands (Kuyper and van der Werf, 2003).

In January 2000, four months after entering secondary education, all students were administered a subset of the traditional Dutch Cito test used to sort students across secondary education tracks. This test assessed math ability, verbal ability and information processing ability. Each ability was assessed using a battery of 20 multiple choice items.

2. Please note that these individuals have either not yet, or else just recently, entered the labour market. Data on their labour market outcomes is therefore not yet available. 
In February 2001 of the second year of the cohort study, students were administered the FiveFactor Personality Inventory (FFPI; Hendriks, Hofstee, and de Raad, 1999) which assesses the Big Five personality dimensions: extraversion, agreeableness, conscientiousness, emotional stability, and openness to experience. The questionnaire contained 100 items on a five-point scale ranging from 1 (not at all accurate) to 5 (fully accurate). Each personality dimension was assessed using 10 positively and 10 negatively formulated items. The data set contains the factor scores computed by the FFPI scoring program (Hofstee and Hendriks, 1998). The constructed Big Five factors are uncorrelated. The internal consistency reliability (stratified-alpha) of extraversion is $\mathrm{a}=0.841$, of agreeableness $\mathrm{a}=$ 0.82 , of conscientiousness $\mathrm{a}=0.84$, of emotional stability $\mathrm{a}=0.83$, and of openness to experience $\mathrm{a}=$ 0.72 . For analysis, all measures of personality traits and cognitive ability were standardized to have a mean of zero and a standard deviation of one.

Personality traits measured at age 14 can be considered a good proxy for personality traits at the time of choosing a field of study, four to five years later. Despite individuals' maturation, differential continuity of personality in childhood, adolescence and young adulthood has been found to be strong: the vast majority of individuals keep their relative position within the personality trait distribution over time (Roberts, Caspi and Moffit, 2001; de Fruyt et al., 2006).

After having registered background information as well as test and personality scores, individuals' pathways were followed until 2009 or until they left education. In my sample, the vast majority of those individuals entering university education did so in 2005 and 2006 at age 18 to $19 .^{3}$ I use detailed information on the field of study individuals have chosen in their first year in university and group them into six commonly used broader field of study categories 1) Humanities, 2) Social Sciences (excluding Business, Economics and Law), 3) Business and Economics, 4) Law, 5) Science, Technology, Engineering and Mathematics (STEM), and 6) Medical Studies. ${ }^{4}$ Higher education institutions with a professional orientation, sometimes also referred to as universities of applied sciences or higher professional education (Dutch: hbo), are not incorporated in this study. This type of education is distinct from university education (Dutch: wo) and including it in the analysis would diminish international comparability of the results. As female and male students have different personality trait endowments but also make different field of study choices I run regressions separately for men and women. Table 2 shows that the sample is broadly nationally representative with regard to the percentage of individuals who enrol in university as well as the distribution across fields of study.

[Table 2]

Tables 3 and 4 present the means and standard deviations of personality traits and cognitive skills both by level of educational attainment and by field of study. Personality traits and cognitive skills with large mean differences between educational levels are likely to be related to individuals' educational attainment. For instance, differences of openness to experience are substantial between educational attainment levels for both men and women, suggesting that this trait plays a major role with regard to individuals' probability of going to university. With regard to fields of study, differences of openness to experience are less pronounced, with a high mean level in Law being an exception. Rather, differences between fields of study seem to be most substantial with regard to extraversion, indicating that extraversion is important for sorting into particular fields of study. In the analysis in section 3, I will use standardized measures of personality traits and cognitive skills. Moreover, I will present the regression results in terms of average marginal effects. While mean comparisons already give some indication about sorting into different educational levels and fields of study, average marginal effects draw a clearer picture about the percentage change in the probability

3. The Dutch secondary education allows for some flexibility. Changing from lower tracks to the academic track, which is a prerequisite for university, is possible but often linked to repeating grades. This explains the low percentage of students entering university after 2006.

4. For a description of how study programmes are grouped into the six categories see Appendix table A1. Study programmes belonging to the category of agricultural and environmental studies are omitted from the analysis as they only contain 17 women and 22 men. 
of going to university (choosing a particular field of study) associated with a one standard deviation change of the respective personality trait or cognitive skill.

[Table 3]

[Table 4]

I will estimate the effect of personality traits and cognitive skills on individuals' probability of going to university using an ordered probit model where the ranked dependent variable is vocational education, higher professional education, and university. In particular, I am interested in the change of individuals' probability of going to university $\left(P_{i c}\right)$ as a result of a one standard deviation change in the scores on a particular Big Five personality trait or cognitive skill $\left(x_{k}\right)$ given by:

$$
\frac{\partial P_{i c}}{\partial x_{i k}}=\beta_{k} \phi\left(\alpha_{2}-x_{i}^{\prime} \beta\right)
$$

where $\alpha_{2}$ is the estimated second cut-off point of the ordered probit regression and $x_{i}$ the is vector of independent variables including the measures of personality traits and cognitive skills; indicators for highest parental education, and a dummy which is one if the individual has a migration background.

I model the field of study choice as a choice between six discrete alternatives and use a multinomial logit framework to estimate how the Big Five personality traits as well as cognitive skills relate to this choice. The probability that individual $i$ chooses field of study $j$ is

$$
\operatorname{Pr}\left(Y_{i}=j \mid x_{i}\right)=P_{i, j}=\frac{\exp \left(x_{i}^{\prime} \beta_{j}\right)}{1+\sum_{k=1}^{J} \exp \left(x_{i}^{\prime} \beta_{k}\right)}, j=0,1, \ldots, 5
$$

where $\beta_{0}$ has been normalized to equal $0 . X_{i}$ is the same vector of independent variables as used in the ordered probit model of educational attainment, with additional indicators of father's occupation as control for differences in information sets. The marginal effect of independent variable $x_{h}$ on an individual's probability of choosing field of study $j$ depends on the coefficients of all fields of study $\left(\beta_{h k}\right)$ and is given by:

$$
\frac{\partial P_{i, j}}{\partial x_{i h}}=P_{i, j}\left[\beta_{h j}-\sum_{k=0}^{J} P_{i, k} \beta_{h k}\right]
$$

\section{Results}

Before proceeding to the main results on field of study choice, it is worthwhile to briefly examine how personality traits affect the probability of entering university. Table 5 displays the average marginal effects of personality traits and cognitive skills on the probability of going to university. Average marginal effects were obtained from an ordered probit regression of educational attainment where the ranked dependent variable is vocational education, higher professional education, and 
university education. The ordered probit regression implies that all three measures of cognitive skills as well as agreeableness, conscientiousness, and openness to experience increase both women's and men's probability of going to university. For women, emotional stability is also positively related to educational attainment. Cognitive skills seem to be the primary driver of educational attainment. For example, a one standard deviation increase in math ability is associated with an increase in the probability of entering a university of 7.8 percentage points for women and 8.4 percentage points for men. These effects are very large given that only around 16 to 17 percent of women and men in our sample go to university. Of the personality traits that influence individuals' probability of going to university, conscientiousness has the largest effect. A one standard deviation increase in conscientiousness is associated with an increase in probability of entering university of 1.8 percentage points for women and 2.7 percentage points for men. While much smaller than the impact of cognitive skills, this effect is substantial and amounts to a relative increase of the probability of entering university by $11 \%$ for women and $16 \%$ for men. Openness to experience affects the probability of going to university equally for women and men (1.3 percentage points). Men and women with a one standard deviation higher score on openness to experience are about $8 \%$ more likely to go to university. Agreeableness has the smallest effect on individuals' educational attainment, especially for women. A one standard deviation increase in agreeableness increases the probability of going to university by 0.6 percentage points $(4 \%)$ for women and 1.1 percentage points $(6 \%)$ for men.

The positive impact of conscientiousness and openness to experience on educational attainment is consistent with the findings of O'Connor and Paunonen (2007) who report a positive relationship between these two personality traits and academic success. More conscientious individuals are thought to be more motivated to succeed academically and have the tendency to be organized, hard-working, and achievement oriented. Openness to experience has been found to be related to measures of intelligence (Chamorro-Premuzic and Furnham, 2005) and the positive relationship between openness to experience and academic success has often been interpreted in this light. With regard to the relation between agreeableness and academic success, O'Connor and Paunonen (2007) conclude that evidence is mixed: while some studies find a negative relationship between agreeableness and academic success, some find a positive. All studies, however, find only small effects. The results from table 5 add to the evidence that the relationship is positive.

\section{[Table 5]}

Table 6 presents the average marginal effects of personality traits and cognitive skills on the probability of choosing a particular field of study by gender. The results are conditional on entering university, thus net of the effect of personality traits on entering university. The results indicate that extraversion has one of the strongest associations with field of study choice. For both women and men, higher extraversion is associated with a higher probability of choosing Law and a lower probability of choosing a STEM field of study in university.

\section{[Table 6]}

A one standard deviation increase of extraversion decreases the probability of choosing STEM fields by 7.8 percentage points for men and 2.5 percentage points for women. While the absolute effect is larger for men, the relative effect is larger for women. Given that STEM field enrolment rates in our sample are $30.8 \%$ for men and only $7.5 \%$ for women, men with a one standard deviation higher score on extraversion are $25 \%$ less likely to enrol in a STEM field, whereas women with a similarly higher score on extraversion are 33\% less likely to enrol in a STEM field. With regard to choosing Law in university, a one standard deviation increase in extraversion increases the probability of choosing this field of study by $46 \%$ ( 3.6 percentage points) for women and $42 \%$ (1.8 percentage points) for men. The multinomial logit model further implies that extraversion is associated with choosing Business, 
Economics and Medical Studies for men; for women, it associates with Social Sciences and Humanities. Men who score one standard deviation higher on extraversion are 10\% (2.9 percentage points) more likely to choose Business and Economics and 20\% (2.2 percentage points) more likely to choose Medical Studies. In contrast, women who score one standard deviation higher on extraversion are $7 \%$ (2.5 percentage points, marginally significant) more likely to choose Social Sciences and 14\% (2.7 percentage points) less likely to choose Humanities. Increasing levels of extraversion seem to shift young men's field of study choice from STEM to Law, Business, Economics and Medical Sciences. For women, increasing levels of extraversion seems to shift field of study choice from STEM and Humanities to Social Sciences and Law. All other things being equal, Social Sciences, Business, Economics, Law and Medical Studies seem to fit extroverts better in terms of the opportunity for social interaction, for persuading others, and for being the focus of attention. In the words of Sherwin Rosen: "Musicians cannot be tone-deaf; football players tend to be large; while lawyers, and many economists, have a propensity to talk" (Rosen, 2002:9).

Agreeable individuals are persons who are considered warm and who enjoy helping others. One might therefore expect that agreeable individuals have a comparative advantage in, and would have a preference for, fields of study involving healthcare, such as Medical Studies, or fields of study concerned with the functioning of societies, such as the Social Sciences (excluding Business, Economics and Law). In line with this reasoning, Judge and Cable (1997) find that more agreeable job seekers are more attracted to supportive and team-oriented organizational cultures and less attracted to aggressive, outcome-oriented, and decisive organizational cultures. The results of the multinomial logit model are consistent with these findings, yet only for men. Men who score one standard deviation higher on agreeableness are 22\% (2.4 percentage points) more likely to choose Medical Studies, $16 \%$ ( 2.1 percentage points, marginally significant) more likely to choose Social Sciences and 9\% (2.7 percentage points, marginally significant) less likely to study Business or Economics. The latter effect is perfectly in line with the findings of Cobb-Clark and Tan (2011) who show that for men, a one standard deviation increase in agreeableness is associated with a 2.8 percentage point decrease in the probability of being a manager, and a 2.9 percentage point decrease in the probability of being a business professional. This finding strongly suggests that the occupational sorting on the basis of personality traits found by Cobb-Clark and Tan (2011) already starts in late adolescence when choosing a field of study.

The results from the ordered probit regression of educational attainment presented in Table 5 highlighted the substantial influence of conscientiousness and openness to experience on individuals' probability of entering university. They are, however, also associated with field of study choice, yet less prominently and with some differences between women and men. Women who score one standard deviation higher on openness to experience are $11 \%$ (2.1 percentage points, marginally significant) more likely to choose Humanities and 10\% (3.4 percentage points) less likely to enroll in Social Sciences in university. Men who score one standard deviation higher on openness to experience are 26\% (1.1 percentage point, marginally significant) more likely to choose Law in university. Conscientiousness affects field of study choice similarly for women and men. Women with a one standard deviation higher score on conscientiousness have a $14 \%$ higher probability of choosing Medical Studies and men with a one standard deviation higher score on conscientiousness have an 18\% (2.0 percentage points) higher probability of sorting into Medical Studies. The effects of openness to experience are somewhat puzzling, given that it is not obvious that the Social Sciences are less intellectually challenging or should offer fewer opportunity for aesthetic and cultural experiences than the Humanities or Law. However, there are two potential explanations for the finding that conscientiousness is positively related to the probability of studying Medical Sciences. Firstly, access to Medical studies is restricted in the Netherlands. Access is granted via a weighted lottery in which high school grades are taken into account. Conscientiousness is related to academic achievement (O'Connor and Paunonen, 2007) and this could account for the effect I have identified. Secondly, although conscientiousness increases productivity in all occupations, the expected rewards of productivity are high for doctors. ${ }^{5}$

5. 10 years after graduation, the average monthly gross earnings of Medical students are 6000 Euro, followed by Business and Economics students (5600 Euro) and Law students (5100 Euro). In contrast, Psychology and Neuroscience students 
Emotional stability - to be calm, self-confident and cool rather than insecure, anxious, depressed and emotional - is positively related to the probability of enrolling in STEM fields for women and negatively linked to the probability of choosing Humanities for both genders. A one standard deviation increase in emotional stability is associated with a $12 \%$ (2.4 percentage point) decrease in the probability of choosing Humanities for women, and a 35\% (3.1 percentage points) decrease for men. The same change in emotional stability increases women's probability of enrolling into STEM fields by $23 \%$ (1.7 percentage points). The positive effect of emotional stability on choosing a STEM field of study in university is consistent with the findings of Cobb-Clark and Tan (2011) who present evidence that emotional stability is positively related to sorting into Science and Engineering professions. They find this relationship, however, for both women and men.

A potential explanation of the effect of emotional stability on field of study choice is that emotional stability is positively related to being a conventional vocational interest type (De Fruyt and Mervielde, 1997). Consequently, more emotionally stable individuals may sort into STEM fields because they enjoy structured environments and rules and therefore dislike the seemingly unstructured environment of Humanities and the Social Sciences. Following Holland's (1997) description of more artistic work environments and personality types, it may also be that the more disorderly and emotionally charged nature of individuals studying humanities is an important stimulus for their more artistic activities, and might, in the end, represent a comparative advantage in tasks related to this field of study. A third explanation is that less emotionally stable individuals exhibit higher career indecision (Tokar, Fischer and Subich, 1998). As the Humanities have weaker links to particular occupations and careers than STEM fields, the associations I have found may be the result of individuals' postponing their career decision by choosing Humanities.

The results for math ability and verbal ability are in line with the findings of Turner and Bowen (1999), although they differ in some respects. Higher math ability increases the probability of choosing STEM fields and decreases the probability of choosing Humanities, yet only for women. The results deviate from those of Turner and Bowen (1999) in that they find similar effects for both genders. Some of the differences between their results and mine can be attributed to the fact that I am able to control for information processing ability in addition to math and verbal ability. Excluding information processing ability from the regression (not shown here) results in the positive effect of math ability on the probability of choosing a STEM field of study to become stronger and statistically significant for men. The negative effect of math ability on the probability of choosing Humanities remains, however, insignificant. This suggests that the effect of math ability found by Turner and Bowen (1999) stems at least partly from the positive correlation between math ability and information processing ability ( 0.41 in my sample).

The impact of math ability on field of study choice is substantial. For women, a one standard deviation increase in math ability increases the probability of enrolling in a STEM field of study by 49\% (3.7 percentage points) and decreases the probability of enrolling in Humanities by $17 \%$ (3.3 percentage points). For men, a similar increase in math ability decreases the probability of choosing Law in university by $41 \%$ (1.8 percentage points).

The effects of verbal ability are, again with some deviations, comparable to those of Turner and Bowen (1999). Verbal ability increases the probability of choosing Humanities in university similarly for both genders. For women, a one standard deviation increase in verbal ability increases the probability of choosing Humanities by about $23 \%$ (4.5 percentage points), while for men the same increase in verbal ability is associated with a $25 \%$ (2.7 percentage points) increase in the probability of choosing Humanities in university. For women, math and verbal ability seem to work in opposite directions. For men, this is not the case. While verbal ability, similar to math ability, influences the decision to choose a STEM field of study for women, it instead affects the decision to study Business or Economics for men. Women with a one standard deviation higher verbal ability are about $41 \%$ (3.1 percentage points) less likely to choose a STEM field of study in university. Men with similar verbal ability are some $12 \%$ (3.4 percentage points) less likely to choose Business or Economics.

I have found that higher information processing ability shifts women's field of study choice from Social Sciences to Medical Sciences and men's field of study choice from Humanities to STEM fields.

(Humanities and Social Sciences category) earn an average of 3500 Euro gross per month 10 years after leaving university. Source: ROA (2011). Maastricht University graduate survey (UM Scanner). 
Women with a one standard deviation higher information processing ability are some $11 \%$ (3.7 percentage points) less likely to study Social Sciences and 15\% (2.6 percentage points, marginally significant) more likely to choose Medical Studies. Men with similarly higher information processing ability are $25 \%$ (2.7 percentage points) less likely to study Humanities and some 10\% (3.1 percentage points, marginally significant) more likely to choose a STEM field of study. A potential explanation for these findings is that Medical Sciences and STEM fields are known to involve a tight curriculum which necessitates higher than average information processing ability. Women who seek challenges seem to choose Medical Studies while men who seek challenges choose STEM fields of study. ${ }^{6}$

\section{Conclusion}

This paper shows that the Big Five personality traits have a significant influence on individuals' field of study choice. The findings suggest that personality traits are already affecting occupational sorting of the highly skilled when they are entering university.

In many respects, personality affects field of study choice similarly for women and men. For both genders, higher verbal ability increases, and higher emotional stability decreases, the probability of choosing Humanities in university. As well, higher levels of extraversion are associated with a higher probability of choosing Law and a lower probability of choosing STEM fields for both women and men. In addition, higher levels of conscientiousness increase both women's and men's probability of choosing Medical Studies. There are, however, substantial differences in how women and men sort into fields of study based on their personality and cognitive skills. This is most apparent for fields of study such as Business and Economics, STEM fields, and Medical Studies; for these, sorting of women and men seems to follow different rules. As elaborated by Turner and Bowen (1999), Zafar (2013), and Antecol and Cobb-Clark (2013), the reasons for this may be gender differences in the weights allocated to post-university opportunities or gender differences in labour market (dis-) incentives. For instance, the non-existent effect of disagreeableness on choosing Business or Economics in university for women is in line with Judge, Livingston and Hurst's (2012) finding that, due to conventional gender roles, the wage returns for disagreeableness are higher for men than they are for women.

While cognitive skills are the primary driver of the probability of entering university, the effects of personality traits and cognitive skills are similar (the differences not statistically significant) with regard to field of study choice. In the case of sorting into STEM fields for men, extraversion is even more important than information processing ability.

With regard to policies aimed at increasing the supply of graduates in fields of study such as Engineering that are considered crucial for economic development, my findings seem to suggests that influencing young individuals' personalities towards introversion and emotional stability would increase the enrolment rates in STEM fields. This, however, presupposes a causal interpretation of the results which is not warranted: in the estimation framework used in this study, personality traits capture various productive factors and preferences and it is not obvious that when personality traits are changed, these will change, too. Rather, my findings confirm the importance of taking individuals' preferences for subject matters and work environments into account when designing policies aimed at managing flows into particular fields of study. Given the importance of these preferences for field of study choice, providing moderate monetary incentives for choosing STEM fields will not significantly increase enrolment rates in these fields.

6. In the 2005 REFLEX survey, Dutch university graduates in the Humanities and Social Sciences (excluding Business, Economics and Law) reported studying for 30 and 27 hours per week respectively. In contrast, self-reported hours spent studying per week were 37 for STEM graduates and 38 for graduates in Medical Studies. Similarly, when rating whether their studies were regarded as demanding on a five point scale, graduates in the Humanities and Social Sciences rated their studies 2.7 and 2.6 respectively, while STEM graduates reported 3.8 and graduates in Medical Studies 3.7. Appendix tables A3 and A4 report hours spent studying and demandingness for all six fields of study. 


\section{References}

Antecol, H., Cobb-Clark, D., 2013. Do psychosocial traits explain gender segregation in young people's occupations? Labour Economics 21, 59-73.

Arcidiacono, P., 2004. Ability sorting and the returns to college major. Journal of Econometrics 121(1-2), 343-375.

Arcidiacono, P. , Hotz, V. J., Kang, S., 2012. Modeling college major choices using elicited measures of expectations and counterfactuals. Journal of Econometrics 166 (1), 3-16.

Barón, J. D., Cobb-Clark, D. A., 2010. Are Young People's Educational Outcomes Linked to their Sense of Control? IZA Discussion Papers 4907, Institute for the Study of Labor (IZA).

Barrick, M.R, Mount, M.K., 1991. The Big Five personality dimensions and job performance: a metaanalysis. Personnel Psychology 44, 1-26.

Berger, M.C., 1988. Predicted Future Earnings and Choice of College Major. Industrial and Labor Relations Review 41(3), 418-429.

van Berkel, K., 1999. Steekproef voor schoolloopbaan onderzoek VOCL'99. Heerlen: Statistics Netherlands.

Borghans, L., Duckworth, A.L., Heckman, J.J., ter Weel, B., 2008. The Economics and Psychology of Personality Traits. Journal of Human Resources 43(4), 972-1059.

Borghans, L., ter Weel, B., Weinberg, B.A., 2008. Interpersonal styles and labour market outcomes. Journal of Human Resources 43(4), 815-858.

Cattan, S., 2010. Heterogeneity and Selection in the Labor Market. PhD Thesis, Economics Department, University of Chicago.

Chamorro-Premuzic, T., Furnham, A., 2005. Personality and intellectual competence. Mahwah, NJ: Lawrence Erlbaum Associates.

Cobb-Clark, D., Tan, M., 2011. Noncognitive Skills, Occupational Attainment, and Relative Wages. Labour Economics 18(1), 1-13.

Costa, P. T., McCrae, R. R., 1985. The NEO personality inventory manual. Odessa, FL: Psychological Assessment Resources.

Cunha, F., Heckman J., 2007. The Technology of Skill Formation. American Economic Review 97(2), $31-47$.

Filer, R.K., 1986. The role of personality and tastes in determining occupational structure. Industrial and Labor Relations Review 39 (3), 412-424.

Flyer, F.A., 1997. The Influence of Higher Moments of Earnings Distributions on Career Decisions. Journal of Labor Economics 15(4), 689-713.

de Fruyt, F., Mervielde, I., 1997. The Five-Factor Model of Personality and Holland's RIASEC Interest Types. Personality and Individual Differences 23(1), 87-103.

de Fruyt, F., Bartels, M., van Leeuwen, K.G., de Clercq, B., Decuyper, M., Mervielde, I., 2006. Five Types of Personality Continuity in Childhood and Adolescence. Journal of Personality and Social Psychology 91(3), 538-552.

Hofstee, W. K. B., Hendriks, A. A. J., 1998. The use of scores anchored at the scale midpoint in reporting individuals' traits. European Journal of Personality 12, 219-228.

O'Connor, M.C., Paunonen, S.V., 2007. Big Five personality predictors of post-secondary academic performance. Personality and Individual Differences 43, 971-990.

Heckman, J. J., Stixrud, J., Urzua, S., 2006. The Effects of Cognitive and Noncognitive Abilities on Labor Market Outcomes and Social Behavior. Journal of Labor Economics 24(3), 411-482.

Heineck, G., Anger, S., 2010. The return to cognitive abilities and personality traits in Germany. Labour Economics 17, 535-546.

Hendriks, J.A.A., Hofstee W.K.B., de Raad, B., 1999. The Five-Factor Personality Inventory (FFPI). Personality and Individual Differences 27, 307-325.

Holland, J. L. , 1997. Making Vocational Choices: A Theory of Vocational Personalities and Work Environments, $3^{\text {rd }}$ Edition, Odessa, FL: Psychological Assessment Resources.

Judge, T. A., Cable, D.M., 1997. Applicant Personality, Organizational Culture, And Organization Attraction. Personnel Psychology 50, 359-394. 
Judge T.A., Livingston, B.A., Hurst, C., 2012. Do Nice Guys—and Gals-Really Finish Last? The Joint Effects of Sex and Agreeableness on Income. Journal of Personality and Social Psychology $102(2), 390-407$.

Krueger, A.B., Schkade, D., 2008. Sorting in the Labor Market: Do Gregarious Workers Flock to Interactive Jobs? Journal of Human Resources 43(4), 859-883.

Kuyper, H., van der Werf, M. P. C., 2003. VOCL'99: De resultaten in het eerste leerjaar. Groningen: GION.

Mount, M. K., Barrick, M. R., Stewart, G. L., 1998. Five-factor model of personality and Performance in jobs involving interpersonal interactions. Human Performance 11, 145-165.

Mueller, G., Plug, E.J.S., 2006. Estimating the Effect of Personality on Male and Female Earnings. Industrial and Labor Relations Review 60(1), 1-22.

Nyhus, E. K., Pons, E., 2005. The effects of personality on earnings. Journal of Economic Psychology 26, 363-384.

ROA, 2011. Maastricht University graduate survey (UM Scanner), Research Centre for Education and the Labour Market.

Available at: http://www.roa.unimaas.nl/projects/umscanner/umscanner.htm (October 2013)

Roberts, B., Caspi, A., Moffit, T., 2001. The Kids Are Alright: Growth and Stability in Personality Development From Adolescence to Adulthood. Journal of Personality and Social Psychology 81(4), 670-683.

Rosen, S., 2002. Markets and Diversity. American Economic Review 92, 1-15.

Tokar, D. M., Fischer, A.F., Subich, M., L., 1998. Personality and Vocational Behavior: A Selective Review of the Literature, 1993-1997. Journal of Vocational Behavior 53 (2), 115-153.

Turner, S.E., Bowen, W.G., 1999. The Changing (Unchanging) Gender Gap. Industrial and Labor Relations Review 52 (2), 289-313.

Wiswall, M., Zafar, B., 2013. Determinants of College Major Choice: Identification Using an Information Experiment. Federal Reserve Bank of New York Staff Reports, no. 500.

Zafar, B., 2013. College Major Choice and the Gender Gap. Journal of Human Resources 48 (3), 545595. 
Table 1: The Big Five Personality traits and their definitions

\begin{tabular}{ll}
\hline Personality trait & Definition \\
\hline Openness to experience & The tendency to be open to new aesthetic, cultural, or intellectual experiences. \\
The tendency to be organized, responsible, and hardworking. \\
$\begin{array}{l}\text { Extraversion } \\
\text { things rather than the inner world of subjective experience; characterized by positive } \\
\text { affect and sociability. }\end{array}$ \\
$\begin{array}{l}\text { Agreeableness } \\
\begin{array}{l}\text { Emotional stability } \\
\text { (Neuroticism) }\end{array}\end{array} \quad \begin{array}{l}\text { Emotional stability is predictability and consistency in emotional reactions, with absence } \\
\text { of rapid mood changes. } \\
\text { Neuroticism is a chronic level of emotional instability and proneness to psychological } \\
\text { distress. }\end{array}$ \\
\hline Definitions from American Psychological Association Dictionary (2007) cited in Almlund et al. (2011).
\end{tabular}

Table 2: Comparison of Sample to National Distribution

\begin{tabular}{|c|c|c|c|c|c|c|}
\hline & \multicolumn{3}{|c|}{ Women } & \multicolumn{3}{|c|}{ Men } \\
\hline & \multicolumn{2}{|c|}{ Sample } & \multirow{2}{*}{$\begin{array}{c}\text { Nationally } \\
\%\end{array}$} & \multicolumn{2}{|c|}{ Sample } & \multirow{2}{*}{$\begin{array}{c}\text { Nationally } \\
\%\end{array}$} \\
\hline & $N$ & $\%$ & & $N$ & $\%$ & \\
\hline \multicolumn{7}{|l|}{$\begin{array}{l}\text { Enrolment in the year after secondary } \\
\text { education: }\end{array}$} \\
\hline Post-secondary vocational education (mbo) & 3610 & 54.2 & 60.0 & 3793 & 57.9 & 64.6 \\
\hline Higher professional education (hbo) & 2002 & 30.0 & 25.5 & 1650 & 25.2 & 21.3 \\
\hline \multirow[t]{2}{*}{ University education (wo) } & 1051 & 15.8 & 14.5 & 1114 & 17.0 & 14.1 \\
\hline & 6663 & & & 6557 & & \\
\hline \multicolumn{7}{|l|}{ Field of study (university only) } \\
\hline Humanities & 201 & 19.4 & 17.8 & 119 & 10.9 & 10.3 \\
\hline Social Sciences & 351 & 34.0 & 32.6 & 147 & 13.5 & 13.8 \\
\hline Law & 81 & 7.8 & 14.9 & 47 & 4.3 & 10.4 \\
\hline Business, Economics & 142 & 13.7 & 10.0 & 324 & 29.7 & 25.5 \\
\hline Science, Technology, Engineering, Mathematics & 78 & 7.5 & 9.2 & 336 & 30.8 & 31.6 \\
\hline \multirow[t]{2}{*}{ Medical Studies } & 181 & 17.5 & 15.5 & 119 & 10.9 & 8.4 \\
\hline & 1034 & & & 1092 & & \\
\hline
\end{tabular}

Note: mbo: middelbar beroepsonderwijs, hbo: hoger beroepsonderwijs, wo: wetenschappelijk onderwijs. Nationwide enrolment in the year after secondary education was calculated on the basis of data of the Dutch statistical office on students' transition from secondary to post-secondary or higher education in 2005. About $9 \%$ of women and men in our sample and $11 \%$ nationally did not continue education after secondary education. This category is omitted in the table and the analysis of educational attainment. 2187 observations for women and 2253 observations for men are lost due to missing personality and cognitive skill measures. Nationwide field of study choice is based on data of the Dutch statistical office and the Association of Universities in the Netherlands (VSNU) for the year 2005. 17 women and 22 men in agricultural and environmental studies were omitted from the analysis of field of study choice due to the small size of this category. 
Table 3: Personality traits and cognitive skills by educational level and gender

\begin{tabular}{|c|c|c|c|c|c|c|}
\hline & & $\begin{array}{l}\text { Women } \\
\text { Mean } \\
\text { (s.d.) }\end{array}$ & & & $\begin{array}{l}\text { Men } \\
\text { Mean } \\
\text { (s.d.) }\end{array}$ & \\
\hline & $\begin{array}{c}\text { Post- } \\
\text { secondary } \\
\text { vocational } \\
\text { education }\end{array}$ & $\begin{array}{c}\text { Higher } \\
\text { professional } \\
\text { education }\end{array}$ & University & $\begin{array}{c}\text { Post- } \\
\text { secondary } \\
\text { vocational } \\
\text { education }\end{array}$ & $\begin{array}{l}\text { Higher } \\
\text { professional } \\
\text { education }\end{array}$ & University \\
\hline \multirow[t]{2}{*}{ Extraversion } & 1.31 & 1.41 & 1.35 & 0.97 & 1.12 & 1.04 \\
\hline & $(0.85)$ & $(0.84)$ & $(0.85)$ & $(0.85)$ & $(0.83)$ & $(0.85)$ \\
\hline \multirow[t]{2}{*}{ Agreeableness } & 1.97 & 2.25 & 2.26 & 1.22 & 1.53 & 1.69 \\
\hline & $(1.07)$ & $(0.96)$ & $(0.92)$ & $(1.06)$ & $(1.02)$ & $(0.99)$ \\
\hline \multirow[t]{2}{*}{ Conscientiousness } & 0.29 & 0.37 & 0.33 & 0.38 & 0.48 & 0.56 \\
\hline & $(1.08)$ & $(1.02)$ & $(1.02)$ & $(1.01)$ & $(1.04)$ & $(1.04)$ \\
\hline \multirow[t]{2}{*}{ Emotional Stability } & 0.82 & 0.97 & 1.02 & 1.14 & 1.35 & 1.35 \\
\hline & $(0.93)$ & $(0.91)$ & $(0.84)$ & $(0.88)$ & $(0.84)$ & $(0.84)$ \\
\hline \multirow[t]{2}{*}{ Openness to Experience } & 0.37 & 0.53 & 0.69 & 0.46 & 0.59 & 0.69 \\
\hline & $(0.87)$ & $(0.86)$ & $(0.86)$ & $(0.83)$ & $(0.83)$ & $(0.86)$ \\
\hline \multirow[t]{2}{*}{ Math ability } & 9.96 & 14.18 & 16.02 & 11.23 & 15.12 & 17.00 \\
\hline & $(3.79)$ & $(3.28)$ & $(2.74)$ & $(4.07)$ & $(3.02)$ & $(2.42)$ \\
\hline \multirow[t]{2}{*}{ Verbal ability } & 11.72 & 14.87 & 16.32 & 10.61 & 13.82 & 15.63 \\
\hline & $(3.29)$ & $(2.63)$ & $(2.32)$ & $(3.43)$ & $(2.91)$ & $(2.61)$ \\
\hline \multirow[t]{2}{*}{ Information processing ability } & 10.17 & 13.84 & 15.50 & 10.48 & 14.12 & 16.13 \\
\hline & $(3.49)$ & $(3.12)$ & $(2.94)$ & $(3.83)$ & $(3.26)$ & $(2.92)$ \\
\hline
\end{tabular}

Source: own calculations 
Table 4: Personality traits and cognitive skills by field of study and gender

\begin{tabular}{|c|c|c|c|c|c|c|c|c|c|c|c|c|c|c|}
\hline & & & & $\begin{array}{c}\text { Women } \\
\text { Mean } \\
\text { (s.d.) }\end{array}$ & & & & & & & $\begin{array}{c}\text { Men } \\
\text { Mean } \\
\text { (s.d.) }\end{array}$ & & & \\
\hline & Humanities & $\begin{array}{c}\text { Social } \\
\text { Sciences }\end{array}$ & Law & $\begin{array}{l}\text { Business, } \\
\text { Economics }\end{array}$ & STEM & $\begin{array}{l}\text { Medical } \\
\text { Sciences }\end{array}$ & Overall & Humanities & $\begin{array}{c}\text { Social } \\
\text { Sciences }\end{array}$ & Law & $\begin{array}{l}\text { Business, } \\
\text { Economics }\end{array}$ & STEM & $\begin{array}{l}\text { Medical } \\
\text { Sciences }\end{array}$ & Overal \\
\hline \multirow[t]{2}{*}{ Extraversion } & 1.22 & 1.41 & 1.73 & 1.43 & 1.09 & 1.24 & 1.35 & 1.11 & 1.06 & 1.42 & 1.14 & 0.83 & 1.20 & 1.05 \\
\hline & $(0.96)$ & $(0.81)$ & $(0.70)$ & $(0.79)$ & $(0.85)$ & $(0.83)$ & $(0.85)$ & $(0.81)$ & $(0.86)$ & $(0.68)$ & $(0.79)$ & $(0.91)$ & $(0.75)$ & $(0.85)$ \\
\hline \multirow[t]{2}{*}{ Agreeableness } & 2.23 & 2.28 & 2.29 & 2.24 & 2.27 & 2.27 & 2.26 & 1.63 & 1.81 & 1.72 & 1.59 & 1.66 & 1.94 & 1.69 \\
\hline & $(0.90)$ & $(0.92)$ & $(1.06)$ & $(0.85)$ & $(0.94)$ & $(0.92)$ & $(0.92)$ & (1.04) & $(0.97)$ & $(0.99)$ & $(0.98)$ & $(0.98)$ & $(1.04)$ & $(1.00)$ \\
\hline \multirow[t]{2}{*}{ Conscientiousness } & 0.34 & 0.29 & 0.30 & 0.39 & 0.19 & 0.46 & 0.35 & 0.54 & 0.47 & 0.54 & 0.52 & 0.59 & 0.76 & 0.56 \\
\hline & $(1.00)$ & $(1.00)$ & $(1.12)$ & $(1.03)$ & $(0.96)$ & $(1.02)$ & $(1.01)$ & $(1.02)$ & $(1.13)$ & (1.19) & $(1.05)$ & $(0.97)$ & $(1.08)$ & (1.04) \\
\hline \multirow[t]{2}{*}{ Emotional Stability } & 0.88 & 1.01 & 1.14 & 1.04 & 1.17 & 1.06 & 1.02 & 1.09 & 1.34 & 1.43 & 1.36 & 1.40 & 1.41 & 1.35 \\
\hline & $(0.85)$ & $(0.87)$ & $(0.71)$ & $(0.85)$ & $(0.77)$ & $(0.81)$ & $(0.84)$ & $(0.81)$ & $(0.89)$ & $(0.75)$ & $(0.81)$ & $(0.83)$ & $(0.85)$ & $(0.83)$ \\
\hline \multirow[t]{2}{*}{$\begin{array}{l}\text { Openness to } \\
\text { Experience }\end{array}$} & 0.78 & 0.60 & 0.91 & 0.74 & 0.76 & 0.60 & 0.69 & 0.83 & 0.70 & 0.96 & 0.69 & 0.62 & 0.69 & 0.70 \\
\hline & $(0.90)$ & $(0.86)$ & $(0.80)$ & $(0.81)$ & $(0.89)$ & $(0.86)$ & $(0.86)$ & $(0.91)$ & $(0.86)$ & $(0.82)$ & $(0.85)$ & $(0.88)$ & $(0.74)$ & $(0.86)$ \\
\hline \multirow[t]{2}{*}{ Math ability } & 15.86 & 15.77 & 15.88 & 15.76 & 16.97 & 16.45 & 16.00 & 16.73 & 16.87 & 15.89 & 16.87 & 17.28 & 17.22 & 16.98 \\
\hline & $(2.55)$ & $(2.87)$ & $(2.79)$ & $(2.86)$ & $(2.49)$ & $(2.60)$ & $(2.75)$ & $(2.41)$ & $(2.31)$ & $(2.77)$ & $(2.48)$ & $(2.41)$ & $(2.21)$ & $(2.43)$ \\
\hline \multirow[t]{2}{*}{ Verbal ability } & 16.75 & 16.18 & 16.37 & 16.09 & 15.99 & 16.44 & 16.32 & 15.93 & 15.81 & 15.19 & 15.24 & 15.69 & 16.11 & 15.62 \\
\hline & (2.18) & $(2.32)$ & $(2.18)$ & $(2.51)$ & $(2.53)$ & $(2.28)$ & $(2.33)$ & $(2.54)$ & $(2.37)$ & $(2.63)$ & $(2.75)$ & $(2.68)$ & $(2.26)$ & $(2.61)$ \\
\hline \multirow[t]{2}{*}{$\begin{array}{l}\text { Information processing } \\
\text { ability }\end{array}$} & 15.81 & 15.19 & 15.09 & 15.09 & 16.03 & 15.95 & 15.48 & 15.62 & 16.14 & 16.02 & 15.80 & 16.40 & 16.67 & 16.11 \\
\hline & (2.86) & (2.91) & $(2.70)$ & $(2.98)$ & (3.13) & $(2.97)$ & $(2.94)$ & $(3.38)$ & $(2.74)$ & (3.03) & (3.02) & $(2.88)$ & $(2.31)$ & $(2.93)$ \\
\hline
\end{tabular}

Note: Only individuals enrolled in university. Source: own calculations 
Table 5: Average marginal effects of personality traits and cognitive skills on individuals' probability of going to university (ordered probit model)

\begin{tabular}{lll}
\hline & Women & Men \\
\hline Extraversion & 0.001 & 0.000 \\
Agreeableness & $(0.003)$ & $(0.003)$ \\
& $0.006^{* *}$ & $0.011^{* * *}$ \\
Conscientiousness & $(0.003)$ & $(0.003)$ \\
& $0.018^{* * *}$ & $0.027^{* * *}$ \\
Emotional stability & $(0.003)$ & $(0.003)$ \\
& $0.005^{*}$ & 0.004 \\
Openness to experience & $(0.003)$ & $(0.003)$ \\
Math ability & $0.013^{* * *}$ & $0.013^{* * *}$ \\
Verbal ability & $(0.003)$ & $(0.003)$ \\
& $0.078^{* * *}$ & $0.084^{* * *}$ \\
Information processing ability & $(0.004)$ & $(0.004)$ \\
& $0.060^{* * *}$ & $0.063^{* * *}$ \\
\hline \hline
\end{tabular}

Note: Average marginal effects from an ordered probit model where the ranked dependent variable is vocational education, higher professional education, and university. $* * * \mathrm{p}<0.01, * * \mathrm{p}<0.05$ and $* \mathrm{p}<0.1$. Controls for highest parental education and migration background were included. The pseudo R2 of both underlying ordered probit models (women and men) is 0.32 . For women $\mathrm{N}=6663$, for men $\mathrm{N}=6557$. 
Table 6: Marginal effects of personality traits and cognitive skills on probability of choosing a particular field of study, by gender (average marginal effects)

\begin{tabular}{|c|c|c|c|c|c|c|c|c|c|c|c|c|}
\hline & \multicolumn{2}{|c|}{ " Humanities } & \multicolumn{2}{|c|}{ "Social Sciences } & \multicolumn{2}{|l|}{ Law } & \multicolumn{2}{|c|}{$\begin{array}{l}\text { Business and } \\
\text { Economics }\end{array}$} & \multicolumn{2}{|c|}{$\begin{array}{l}\text { Science, Technology, } \\
\text { Engineering, Mathematics }\end{array}$} & \multicolumn{2}{|c|}{ "Medical Studies } \\
\hline & Women & Men & Women & Men & Women & Men & Women & Men & Women & Men & Women & Men \\
\hline \multirow[t]{2}{*}{ Extraversion } & $-0.027 * *$ & 0.012 & $0.025^{*}$ & -0.003 & $0.036 * * *$ & $0.018 * * *$ & 0.009 & $0.029 * *$ & $-0.025 * * *$ & $-0.078 * * *$ & -0.018 & $0.022 * *$ \\
\hline & $(0.012)$ & $(0.010)$ & $(0.015)$ & $(0.011)$ & $(0.009)$ & $(0.007)$ & $(0.011)$ & $(0.014)$ & $(0.007)$ & $(0.013)$ & $(0.011)$ & $(0.010)$ \\
\hline \multirow[t]{2}{*}{ Agreeableness } & -0.010 & -0.004 & 0.016 & $0.021 *$ & 0.003 & -0.003 & -0.005 & $-0.027^{*}$ & -0.005 & -0.010 & 0.001 & $0.024 * *$ \\
\hline & $(0.012)$ & $(0.010)$ & $(0.015)$ & $(0.011)$ & $(0.010)$ & $(0.006)$ & $(0.011)$ & $(0.014)$ & $(0.009)$ & $(0.015)$ & $(0.013)$ & $(0.011)$ \\
\hline \multirow[t]{2}{*}{ Conscientiousness } & 0.011 & 0.007 & -0.022 & -0.018 & -0.001 & 0.001 & 0.004 & -0.005 & -0.014 & -0.005 & $0.023^{*}$ & $0.020^{* *}$ \\
\hline & $(0.012)$ & $(0.011)$ & $(0.015)$ & $(0.012)$ & $(0.009)$ & $(0.007)$ & $(0.011)$ & $(0.014)$ & $(0.009)$ & $(0.014)$ & $(0.012)$ & $(0.010)$ \\
\hline \multirow[t]{2}{*}{ Emotional stability } & $-0.024 *$ & $-0.031 * * *$ & -0.009 & -0.002 & 0.009 & 0.008 & 0.001 & 0.004 & $0.017 *$ & 0.024 & 0.005 & -0.003 \\
\hline & $(0.012)$ & $(0.009)$ & $(0.015)$ & $(0.012)$ & $(0.008)$ & $(0.006)$ & $(0.011)$ & $(0.014)$ & $(0.009)$ & $(0.015)$ & $(0.012)$ & $(0.010)$ \\
\hline \multirow[t]{2}{*}{ Openness to experience } & $0.021 *$ & 0.013 & $-0.034 * *$ & -0.011 & 0.012 & $0.011 *$ & 0.013 & 0.008 & 0.006 & -0.014 & -0.019 & -0.007 \\
\hline & $(0.013)$ & $(0.011)$ & $(0.015)$ & $(0.011)$ & $(0.009)$ & $(0.006)$ & $(0.011)$ & $(0.014)$ & $(0.008)$ & $(0.015)$ & $(0.012)$ & $(0.010)$ \\
\hline \multirow[t]{2}{*}{ Math ability } & $-0.033 * *$ & -0.007 & -0.021 & -0.012 & -0.002 & $-0.018 * * *$ & -0.003 & 0.014 & $0.037 * * *$ & 0.026 & 0.022 & -0.003 \\
\hline & $(0.013)$ & $(0.010)$ & $(0.016)$ & $(0.012)$ & $(0.010)$ & $(0.007)$ & $(0.011)$ & $(0.016)$ & $(0.011)$ & $(0.017)$ & $(0.014)$ & $(0.011)$ \\
\hline \multirow[t]{2}{*}{ Verbal ability } & $0.045^{* * *}$ & $0.027 * *$ & -0.007 & 0.013 & 0.007 & -0.003 & -0.008 & $-0.034 * *$ & $-0.031 * * *$ & -0.019 & -0.006 & 0.015 \\
\hline & $(0.015)$ & $(0.011)$ & $(0.017)$ & $(0.012)$ & $(0.009)$ & $(0.007)$ & $(0.012)$ & $(0.016)$ & $(0.010)$ & $(0.016)$ & $(0.013)$ & $(0.010)$ \\
\hline \multirow[t]{2}{*}{ Information processing ability } & 0.014 & $-0.027 * * *$ & $-0.037 * *$ & -0.004 & -0.002 & 0.009 & -0.014 & -0.025 & 0.013 & $0.031 *$ & $0.026^{*}$ & 0.015 \\
\hline & $(0.015)$ & $(0.010)$ & $(0.016)$ & $(0.012)$ & $(0.009)$ & $(0.008)$ & $(0.012)$ & $(0.016)$ & $(0.011)$ & $(0.017)$ & $(0.015)$ & $(0.011)$ \\
\hline
\end{tabular}




\section{Appendix A}

Table A1: Mapping of detailed field of study categories to the six categories used in multinomial logit framework by gender

\begin{tabular}{|c|c|c|c|c|c|}
\hline $\begin{array}{l}\text { Broad field of study category used in } \\
\text { study }\end{array}$ & Dutch VOCL99 data fields of study & $\begin{array}{c}\mathrm{N} \\
\text { (women) }\end{array}$ & $\%$ & $\begin{array}{c}\mathrm{N} \\
(\mathrm{men})\end{array}$ & $\%$ \\
\hline \multicolumn{6}{|l|}{ Humanities } \\
\hline & Theology & 3 & 0.29 & 1 & 0.09 \\
\hline & $\begin{array}{l}\text { Languages (Dutch, French, Spanish, } \\
\text { German, English) }\end{array}$ & 80 & 7.74 & 61 & 5.59 \\
\hline & History & 19 & 1.84 & 20 & 1.83 \\
\hline & History of Art/Archaeology & 5 & 0.48 & 2 & 0.18 \\
\hline & Philosophy & 4 & 0.39 & 6 & 0.55 \\
\hline & Humanities-other & 90 & 8.70 & 29 & 2.66 \\
\hline & & 201 & 19.44 & 119 & 10.90 \\
\hline \multicolumn{6}{|l|}{ Social Sciences } \\
\hline & Administrative Studies & 13 & 1.26 & 22 & 2.01 \\
\hline & Physical Education & 11 & 1.06 & 7 & 0.64 \\
\hline & Geography & 5 & 0.48 & 5 & 0.46 \\
\hline & Anthropology/Sociology & 14 & 1.35 & 2 & 0.18 \\
\hline & Health Sciences & 36 & 3.48 & 8 & 0.73 \\
\hline & Sociology & 7 & 0.68 & 8 & 0.73 \\
\hline & Political Sciences & 4 & 0.39 & 12 & 1.10 \\
\hline & Psychology & 113 & 10.93 & 30 & 2.75 \\
\hline & Educational Sciences & 62 & 6.00 & 3 & 0.27 \\
\hline & Social Sciences-other & 86 & 8.32 & 50 & 4.58 \\
\hline & & 351 & 33.95 & 147 & 13.46 \\
\hline \multicolumn{6}{|l|}{ Business and Economics } \\
\hline & Business/Economics & 93 & 8.99 & 183 & 16.76 \\
\hline & Econometrics & 2 & 0.19 & 9 & 0.82 \\
\hline & Technical Business studies & 1 & 0.10 & 24 & 2.20 \\
\hline & Business/Economics-other & 46 & 4.45 & 108 & 9.89 \\
\hline & & 142 & 13.73 & 324 & 29.67 \\
\hline
\end{tabular}

Law

Law

\begin{tabular}{llll}
81 & 7.83 & 47 & 4.30 \\
\hline 81 & 7.83 & 47 & 4.30
\end{tabular}

Mathematics, Natural Sciences, Engineering, other technical studies

\begin{tabular}{lcccc} 
Mathematics & 0 & 0 & 4 & 0.37 \\
Physics & 2 & 0.19 & 0 & 0 \\
Chemistry & 2 & 0.19 & 9 & 0.82 \\
Biology & 13 & 1.26 & 19 & 1.74 \\
Pharmaceutical studies & 5 & 0.48 & 2 & 0.18 \\
Mathematics/Natural Sciences-other & 18 & 1.74 & 61 & 5.59 \\
Technical Mathematics & 3 & 0.29 & 1 & 0.09 \\
Technical Physics & 3 & 0.29 & 26 & 2.38 \\
Technical Chemistry & 0 & 0 & 10 & 0.92 \\
Civil Engineering & 3 & 0.29 & 24 & 2.20 \\
Construction & 8 & 0.77 & 35 & 3.21 \\
Electrotechnology & 0 & 0 & 17 & 1.56 \\
Toolmaking & 4 & 0 & 43 & 3.94 \\
Aerospace & 0 & 0 & 24 & 2.20 \\
Technical studies - others & 17 & 1.64 & 61 & 5.59 \\
\hline & 78 & 7.54 & 336 & 30.77
\end{tabular}




\begin{tabular}{lcccc} 
Medical studies Medicine & 104 & 10.06 & 73 & 6.68 \\
Medical studies other & 53 & 5.13 & 33 & 3.02 \\
Dentistry & 4 & 0.39 & 3 & 0.27 \\
Veterinary & 20 & 1.93 & 10 & 0.92 \\
\cline { 2 - 5 } & 181 & 17.50 & 119 & 10.90 \\
\cline { 2 - 5 } & 1034 & & 1092 & \\
\cline { 2 - 5 }
\end{tabular}

Table A2: Summary statistics of variables used in multinomial logit model of field of study choice

\begin{tabular}{|c|c|c|c|c|}
\hline & \multicolumn{2}{|c|}{ Women } & \multicolumn{2}{|c|}{ Men } \\
\hline & mean & s.d. & mean & s.d. \\
\hline \multicolumn{5}{|l|}{ Personality traits } \\
\hline Extraversion & 1.35 & 0.85 & 1.05 & 0.85 \\
\hline Agreeableness & 2.26 & 0.92 & 1.69 & 1 \\
\hline Conscientiousness & 0.35 & 1.01 & 0.56 & 1.04 \\
\hline Emotional Stability & 1.02 & 0.84 & 1.35 & 0.83 \\
\hline Openness to Experience & 0.69 & 0.86 & 0.70 & 0.86 \\
\hline \multicolumn{5}{|l|}{ Cognitive skills } \\
\hline Math ability & 16.00 & 2.75 & 16.98 & 2.43 \\
\hline Verbal ability & 16.32 & 2.33 & 15.62 & 2.61 \\
\hline Information processing ability & 15.48 & 2.94 & 16.11 & 2.93 \\
\hline \multicolumn{5}{|l|}{ Highest parental education } \\
\hline Low & 0.04 & & 0.03 & \\
\hline $1^{\text {st }}$ step secondary education & 0.05 & & 0.05 & \\
\hline $2^{\text {nd }}$ step secondary education & 0.27 & & 0.27 & \\
\hline Bachelor's degree (ref) & 0.32 & & 0.31 & \\
\hline Master's degree or doctorate & 0.26 & & 0.29 & \\
\hline Parental education missing & 0.06 & & 0.05 & \\
\hline Migration background & 0.19 & & 0.15 & \\
\hline \multicolumn{5}{|l|}{ Father's occupation } \\
\hline Agriculture & 0.03 & & 0.02 & \\
\hline Business, Economics & 0.19 & & 0.19 & \\
\hline Medical Studies & 0.09 & & 0.09 & \\
\hline Government & 0.11 & & 0.10 & \\
\hline STEM & 0.15 & & 0.15 & \\
\hline other & 0.20 & & 0.23 & \\
\hline Father's occupation missing & 0.23 & & 0.22 & \\
\hline
\end{tabular}


Table A3: Mean self-reported hours spent studying per week

$\begin{array}{ll}\text { Humanities } & 30 \\ \text { Social Sciences } & 27 \\ \text { Law } & 25 \\ \text { Business, Economics } & 30 \\ \text { STEM } & 37\end{array}$

Medical Studies $\quad 38$

Source: REFLEX survey, own calculations.

Table A4: Self-reported demandingness of study (5 point scale)

\begin{tabular}{ll} 
Humanities & 2.7 \\
Social Sciences & 2.6 \\
Law & 2.7 \\
Business, Economics & 3.1 \\
STEM & 3.8 \\
Medical Studies & 3.6 \\
\hline
\end{tabular}

Source: REFLEX survey, own calculations. 